\title{
MODEL PENGADAAN TANAH UNTUK PEMBANGUNAN JALAN TOL (PRAKTIK BAIK/BEST PRACTICE PEMBEBASAN TANAH UNTUK JALAN TOL TRANS JAWA RUAS SOLO - MANTINGAN I DI KABUPATEN KARANGANYAR)
}

\section{Erwin Nugroho Suddin, Suparnyo dan Subarkah}

Email : erwinnugroho@gmail.com,suparnyo@umk.ac.id, subarkah_sh@yahoo.com Fakultas Hukum Universitas Muria Kudus

\begin{abstract}
ABSTRAK
Pemerintah menetapkan dan memberlakukan Undang-Undang Nomor 2 Tahun 2012 tentang Pengadaan Tanah bagi Pembangunan untuk Kepentingan Umum. Undang-undang tersebut digunakan sebagai dasar penyelenggaraan dari setiap pengadaan tanah yang dilaksanakan di Indonesia. Untuk menunjang pembangunan yang semakin kompleks, diperlukan jaringan transportasi yang memadai, sehingga pembangunan dapat merata kesemua daerah di seluruh Indonesia. Salah satu jaringan transportasi tersebut adalah Jalan Tol Solo-Mantingan di wilayah Kabupaten Karanganyar. Pembangunan jalan tol Solo-Mantingan dimaksudkan sebagai upaya untuk memperlancar arus lalu lintas dari jalur Solo menuju Mantingan ataupun sebaliknya yang begitu padat.
\end{abstract}

Kata Kunci : Pengadaan Tanah, Jalan Tol, Kabupaten Karanganyar 


\section{PENDAHULUAN}

Tanah merupakan kebutuhan hidup manusia yang sangat mendasar. Manusia hidup serta melakukan aktivitas di atas tanah sehingga setiap saat manusia selalu berhubungan dengan tanah. Dapat dikatakan hampir semua kegiatan hidup manusia baik secara langsung maupun tidak langsung selalu memerlukan tanah.

Negara menguasai tanah dan sumber daya alam di Indonesia dalam rangka pelaksanaan pembangunan Nasional. Penguasaan oleh negara diatur dalam Undang-Undang Dasar Negara Republik Indonesia Tahun 1945 Pasal 33 ayat (3) yang menentukan bahwa : ${ }^{67}$

"Bumi dan air dan kekayaan alam yang terkandung didalamnya dikuasai oleh Negara dan dipergunakan untuk sebesarbesarnya kemakmuran rakyat".

Pelaksanaan dari ketentuan pasal tersebut dijabarkan lebih lanjut dalam Undang-Undang Nomor 5 Tahun 1960 tentang Peraturan Dasar Pokok-Pokok Agraria (selanjutnya disingkat UUPA). Ketentuan Pasal 2 UUPA yang mengatur tentang Hak Menguasai Negara yang pada garis besarnya menentukan bahwa ${ }^{68}$

1) Bumi, air dan ruang angkasa, termasuk kekayaan alam yang terkandung didalamnya dikuasai oleh Negara, sebagai organisasi kekuasaan seluruh rakyat.

2) Hak menguasai dari Negara meliputi wewenang untuk :

\footnotetext{
${ }^{67}$ Boedi Harsono, "Hukum Agraria Indonesia ( Sejarah Pembentukan Undang-Undang Pokok Agraria, Isi dan Pelaksanaannya”, Djambatan, 2003, Jakarta, hlm. 46

${ }^{68}$ Aslan Noor, "Konsepsi Hak Milik Atas Tanah Bagi Bangsa Indonesia'. 2006, Bandung, CV Mandar Maju, hlm. 21
}

a. Mengatur dan menyelenggarakan peruntukkan, penggunaan, persediaan dan pemeliharaan bumi, air dan ruang angkasa.

b. Menentukan dan mengatur hubungan-hubungan hukum antara orang-orang dengan bumi, air dan ruang angkasa.

c. Menentukan dan mengatur hubungan-hubungan hukum antara orang-orang dan perbuatan-perbuatan hukum yang mengenai bumi, air dan ruang angkasa.

3) Wewenang yang bersumber pada hak menguasai dari Negara tersebut digunakan untuk mencapai sebesarbesarnya kemakmuran rakyat, dalam arti kebahagiaan, kesejahteraan dan kemerdekaan dalam masyarakat dan Negara hukum Indonesia yang merdeka berdaulat adil dan makmur.

Pemerintah menetapkan dan memberlakukan Undang-Undang Nomor 2 Tahun 2012 tentang Pengadaan Tanah bagi Pembangunan untuk Kepentingan Umum. Undangundang tersebut digunakan sebagai dasar penyelenggaraan dari setiap pengadaan tanah yang dilaksanakan di Indonesia. Untuk menunjang pembangunan yang semakin kompleks, diperlukan jaringan transportasi yang memadai, sehingga pembangunan dapat merata kesemua daerah di seluruh Indonesia.

Salah satu jaringan transportasi tersebut adalah Jalan Tol SoloMantingan di wilayah Kabupaten Karanganyar. Pembangunan jalan tol Solo-Mantingan dimaksudkan sebagai upaya untuk memperlancar arus lalu lintas dari jalur Solo menuju Mantingan ataupun sebaliknya yang begitu padat. 
Berdasarkan latar belakang sebagaimana diuraikan sebelumnya, maka permasalahan yang akan dipecahkan adalah sebagai berikut :

1. Bagaimana pelaksanaan pengadaan tanah untuk pembangunan jalan tol trans Jawa ruas Solo - Mantingan I di Kabupaten Karanganyar?

2. Faktor-faktor apa yang menyebabkan belum selesainya ganti kerugian dalam proses pengadaan tanah untuk pembangunan jalan tol Trans Jawa ruas Solo-Mantingan I di Kabupaten Karanganyar?

3. Bagaimana upaya Pemerintah untuk menyelesaikan apabila tidak tercapai kata sepakat tentang besaran nilai ganti kerugian dalam pengadaan tanah bagi pembangunan untuk kepentingan umum?

\section{HASIL PENELITIAN DAN PEMBAHASAN}

\section{Hak Atas Tanah}

Berbicara tentang pengertian hak atas tanah, Budi Harsono menjelaskan "Hak atas tanah merupakan hak penguasaan atas tanah yang berisikan serangkaian wewenang, kewajiban dan/atau larangan bagi pemegang haknya untuk berbuat sesuatu mengenai tanah yang dihaki. Sesuatu yang boleh, wajib atau dilarang untuk diperbuat, yang merupakan isi hak penguasaan itulah yang menjadi kriteria atau tolok pembeda diantara hak-hak penguasaan atas tanah yang diatur dalam hukum tanah".

Atas dasar ketentuan tersebut, negara berwenang untuk menentukan hak-hak atas tanah yang dapat dimiliki oleh dan atau diberikan kepada seseorang dan badan hukum yang memenuhi persyaratan yang ditentukan. Kewenangan tersebut diatur dalam Pasal 4 ayat (1) UUPA, yang menyatakan bahwa :

"Atas dasar hak menguasai dari negara sebagaimana yang dimaksud dalam Pasal 2 ditentukan adanya macammacam hak atas permukaan bumi yang disebut tanah, yang dapat diberikan kepada dan dipunyai oleh orang-orang, baik sendiri maupun bersama-sama dengan orang lain serta badan hukum".

Berdasarkan bunyi pasal tersebut, maka negara menentukan hak-hak atas tanah sebagaimana diatur dalam Pasal 16 ayat (1) UUPA, yaitu :

a. Hak milik

b. Hak guna usaha

c. Hak guna bangunan

d. Hak Pakai

e. Hak sewa

f. Hak membuka tanah

g. Hak memungut hasil hutan

h. Hak-hak lain yang tidak termasuk dalam hak-hak tersebut di atas yang akan ditetapkan dengan undangundang serta hak-hak yang sifatnya sementara sebagaimana disebut dalam Pasal 53

Untuk badan hukum yang didirikan menurut hukum Indonesia dan berkedudukan di Indonesia dapat mempunyai semua hak atas tanah kecuali hak milik yang terbatas pada badan-badan hukum yang ditetapkan oleh pemerintah, sebagaimana diatur dalam Pasal 30 ayat (1) huruf $b$ dan Pasal 36 ayat (1) huruf b UUPA. ${ }^{69}$

${ }^{69} \mathrm{Ibid}$ 


\section{Prosedur Pengadaan Tanah}

Prosedur pengadaan tanah yaitu antara lain : ${ }^{70}$

a) Perencanaan

Instansi pemerintah yang memerlukan tanah menyusun proposal rencana pembangunan, yang menguraikan :

1) maksud dan tujuan pembangunan;

2) letak dan lokasi pembangunan;

3) luasan tanah yang diperlukan;

4) sumber pendanaan;

5) analisis kelayakan lingkungan perencanaan pembangunan, termasuk dampak pembangunan, berikut upaya pencegahan dan pengendaliannya

b) Penetapan lokasi

Berdasarkan proposal instansi pemerintah yang memerlukan tanah mengajukan permohonan penetapan lokasi kepada bupati/walikota dengan tembusan ke Kepala Kantor Pertanahan. Bupati/walikota mengkaji kesesuaian rencana pembangunan dari aspek : tata ruang, penatagunaan tanah, sosial ekonomi, lingkungan, serta penguasaan, pemilikan, dan pemanfaatan tanah.

Pelaksanaan pengkajian didasarkan atas rekomendasi instansi terkait dan kantor pertanahan. Berdasarkan rekomendasi bupati/walikota menerbitkan keputusan penetapan lokasi. Setelah diterima keputusan dalam waktu paling lama 14 hari wajib mempublikasikan rencana pelaksanaan pembangunan untuk kepentingan umum.

70 Mudakir Iskandar Syah, "Dasar-Dasar Pembebasan Tanah Untuk Kepentingan Umum”, 2007, Jala Permata, Jakarta, hlm. 20 c) Penyuluhan

Penyuluhan dilakukan oleh panitia pengadaan tanah dan instansi pemerintah, menjelaskan manfaat, maksud dan tujuan pembangunan kepada masyarakat untuk memperoleh kesediaan dari para pemilik. Apabila diterima oleh masyarakat, maka dilanjutkan dengan kegiatan pengadaan tanah. Sedangkan apabila tidak diterima oleh masyarakat, maka panitia pengadaan tanah kabupaten/kota melakukan penyuluhan kembali.

Apabila setelah penyuluhan kembali ternyata tetap tidak diterima oleh $75 \%$ pemilik tanah, maka lokasinya dapat dipindahkan, instansi pemerintah yang memerlukan tanah mengajukan alternatif lokasi lain. Akan tetapi apabila lokasinya tidak dapat dipindahkan ke lokasi lain, maka panitia pengadaan tanah kabupaten/kota mengusulkan kepada bupati/walikota atau gubernur untuk menggunakan ketentuan UU No. $20 \mathrm{Th}$ 1961 tentang Pencabutan Hak-Hak Tanah dan Benda-Benda yang ada diatasnya. Kemudian hasil pelaksanaan penyuluhan dituangkan dalam Berita Acara Hasil Penyuluhan. ${ }^{71}$

d) Identifikasi dan Inventarisasi

Apabila rencana pembangunan diterima oleh masyarakat, maka panitia pengadaan tanah kabupaten/kota melakukan identifikasi dan invetarisasi atas penguasaan, penggunaan dan pemilikan tanah dan/atau bangunan dan atau tanaman dan atau benda lain yang berkaitan dengan tanah.

Kegiatan dalam identifikasi dan inventarisasi yaitu:

\footnotetext{
${ }^{71}$ Muhammad Yamin Lubis dan Abdul Rahman Lubis, "Pencabutan Hak, Pembebasan dan Pengadaan Tanah”, Mandar Maju, 2011, Bandung, hlm. 33
} 
1) Penunjukan batas;

2) Pengukuran bidang tanah dan/atau bangunan;

3) Pemetaan bidang tanah dan/atau bangunan dan atau keliling batas bidang tanah;

4) Penetapan batas-batas bidang tanah dan/atau bangunan;

5) Pendataan penggunaan dan pemanfaatan tanah;

6) Pendataan status tanah dan/atau bangunan;

7) Pendataan penguasaan dan pemilikan tanah dan/atau bangunan dan/atau tanaman; dan

8) Lainnya yang dianggap perlu. Panitia pengadaan tanah kabupaten/kota menunjuk Lembaga Penilai Harga Tanah yang telah ditetapkan bupati/walikota untuk menilai harga tanah yang terkena pembangunan untuk kepentingan umum. Apabila tidak terdapat Lembaga Penilai Harga Tanah, maka penilaian harga tanah dilakukan oleh Tim Penilai Harga Tanah, yang terdiri dari :

1) Instansi bidang bangunan

2) Badan Pertanahan Nasional

3) Instansi Pelayanan Pajak Bumi dan Bangunan

4) Ahli/orang yang berpengalaman sebagai penilai harga tanah

5) Akademisi yang mampu menilai harga tanah, bangunan, tanaman, dan benda terkait dengan tanah

6) LSM (bila diperlukan)

Tim Penilai Harga Tanah melakukan penilaian harga tanah berdasarkan pada NJOP atau nilai nyata/sebenarnya dengan memperhatikan NJOP, dan dapat berpedoman pada variabel-variabel sebagai berikut :

1) Lokasi dan letak tanah

2) Status tanah
3) Peruntukan tanah

4) Kesesuaian penggunaan tanah dengan RTRW

5) Sarana dan prasarana yang tersedia

6) Faktor lain yang mempengaruhi harga tanah

\section{Pelaksanaan Pengadaan Tanah untuk Pembangunan Jalan Tol di Wilayah Kabupaten Karanganyar}

Pada tanggal 14 Agustus 2012 pemerintah menetapkan dan memberlakukan Undang-Undang Nomor 2 Tahun 2012 tentang Pengadaan Tanah bagi Pembangunan untuk Kepentingan Umum. Undangundang tersebut digunakan sebagai dasar penyelenggaraan dari setiap pengadaan tanah yang dilaksanakan di Indonesia. Dalam Pasal 58 dari Undang- undang ini disebutkan bahwa: ${ }^{72}$

1) Proses Pengadaan Tanah yang sedang dilaksanakan sebelum berlakunya Undang-Undang Nomor Tahun 2012 diselesaikan berdasarkan ketentuan Peraturan Presiden Nomor 36 Tahun 2005 juncto Peraturan Presiden Nomo 65 Tahun 2006;

2) Sisa tanah yang belum selesai pengadaannya dalam proses Pengadaan Tanah, Pengadaannya diselesaikan berdasarkan ketentuan yang diatur dalam Undang-Undang Nomor 2 Tahun 2012.

Sebagai tindak lanjut dari UU Nomor 2 Tahun 2012 ini maka pada tanggal 07 Agustus 2012

\footnotetext{
72 Mudakir Iskandar Syah, "Dasar-Dasar Pembebasan Tanah Untuk Kepentingan Umum”, Jala Permata, 2007, Jakarta, hlm. 26
} 
pemerintah

kembali

mengesahkan

Peraturan

Presiden Nomor 71 Tahun 2012

tentang

Penyelenggaraan

Pengadaan Tanah Bagi

Pembangunan Untuk

Kepentingan Umum. Sedangkan untuk petunjuk teknis pelaksanaan pengadaan tanah diatur dalam Peraturan Kepala Badan Pertanahan Nasional Republik Indonesia Nomor 5 Tahun 2012 juncto Peraturan Menteri Agraria dan Tata Ruang/Kepala Badan Pertanahan Nasional Nomor 6 Tahun 2015 tentang perubahan atas Peraturan Kepala Badan Pertanahan Nasional Republik Indonesia Nomor 5 Tahun 2012, juncto Peraturan Menteri Agraria dan Tata Ruang/Kepala Badan Pertanahan Nasional Nomor 22 Tahun 2015 tentang perubahan kedua atas Peraturan Menteri Agraria dan Tata Ruang/Kepala Badan Pertanahan Nasional Nomor 6 Tahun 2015 tentang petunjuk teknis pengadaan tanah.

Proses pengadaan tanah tersebut meliputi pengadaan tanah :

1) Telah dituangkan dalam dokumen perencanaan/ proposal pembangunan;

2) Telah dianggarkan pada tahun anggaran yang sedang berjalan;

3) Telah diterbitkan penetapan lokasi;

4) Telah terlaksana pelepasan hak; dan/atau

5) Ganti kerugian telah dititipkan di pengadilan negeri.
Sejalan dengan isi Pasal 123 dari Perpres Nomor 71 Tahun 2012, maka pada tanggal 15 September 2014 Pemerintah kembali mengesahkan Perpres Nomor 99 Tahun 2014 tentang Perubahan Kedua atas Perpres Nomor 71 Tahun 2012 tentang Penyelenggaraan Pengadaan Tanah bagi Pembangunan untuk Kepentingan Umum. Pada Pasal 123 A dari Perpres ini disebutkan bahwa proses pengadaan tanah yang belum selesai sampai dengan tanggal 31 Desember 2014 tetapi telah mencapai $75 \%$ dari luas kebutuhan tanah, dapat diperpanjang proses pengadaannya sampai dengan tanggal 31 Desember 2015.

Pelaksanaan proyek pembangunan jalan Tol Solo-Mantingan merupakan proyek berkelanjutan yang dikerjakan tiap tahun mulai tahun 2007 sampai dengan tercapainya target pembebasan tanah sesuai masterplan pembangunan dan SK Penetapan Lokasi. Berdasarkan data yang diperoleh penulis dari Panitia Pengadaan Tanah bahwa proses pembayaran ganti rugi untuk pembangunan jalan tol Solo-Mantingan telah mencapai $90 \%$ dari total progress bidang tanah yang akan dibebaskan.

Faktor-Faktor Dalam Pengadaan Tanah Untuk Pembangunan Jalan Tol Trans Jawa di Kabupaten Karanganyar dan Upaya yang Dilakukan Panitia Pengadaan Tanah Untuk Mengatasinya.

Dalam setiap pelaksanaan pengadaan tanah untuk pembangunan kepentingan umum, selalu ada faktor-faktor yang menyebabkan belum selesainya ganti kerugian dalam proses pengadaan tanah untuk pembangunan Jalan Tol Trans Jawa ruas Solo-Mantingan I di Kabupaten 
Karanganyar ini, adapun faktor-faktor yang dihadapi sebagai berikut:

\section{Terjadinya Jual Beli Lahan Secara Bebas}

Terjadinya jual beli lahan (tanah dijual) yang dilakukan oleh pemilik tanahsecara bebas, tanpa melaporkan ke pihak-pihak yang berwenang terhadap persoalan tanah, dalam hal ini BPN. Bahkan terdapat proses pengalihan hak atas tanah secara dibawah tangan, disisi lain tanah yang dimiliki sebelumnya telah ditetapkan sebagai lokasi yang dilintasi/terkena rencana pembangunan jalan tol tersebut.

Setelah ditelusuri lebih jauh mengenai hal tersebut, terdapat 2 alasan kenapa beberapa masyarakat melakukan hal tersebut, yaitu : masyarakat tidak mengetahui akan hal tersebut dan dalam hal masyarakat mengetahui hal tersebut masyarakat tetap menjual tanahnya karena himpitan ekonomi dan kebutuhan masyarakat yang terus berkembang.

Adapun masyarakat yang mengetahui hal tersebut, tapi tetap saja nekat menjualkan tanahnya secara bebas karena kebutuhan ekonomi masyarakat yang selalu berkembang dan ketidak mampuan ekonomi masyarakat tersebut sehingga masyarakat itu menjual tanahnya dengan harapan memperoleh uang lebih cepat.

\section{Terjadinya Proses Waris}

Dalam hal terjadinya proses waris ini, dimana sang ahli waris dalam memperoleh warisan berupa tanah, namun masih belum ditindak lanjuti dengan proses balik nama, sehingga antara dokumen legal dengan realita kepemilikan atas tanah tersebut berbeda. Hal ini tentu membutuhkan penelusuran ulang untuk memastikan siapa pihak yang berhak terhadap tanah tersebut.

\section{Adanya Kepemilikan Tanah} Absentee/Guntai

Maksudnya kepemilkan tanah absentee/guntai disini adalah dimana pemilik tanah tidak berada/atau berdomisili di wilayah dimana tanah tersebut berada, seperti kasus yang terjadi di lapangan dimana Tenaga Kerja Indonesia (TKI) yang jumlahnya cukup banyak yang menginvestasikan uangnya dengan membeli tanah didaerahnya tersebut. Ini dapat mempengaruhi pasaran harga tanah, karena sipemilik tidak merasa perlu buru-buru menjual tanahnya dengan alasan apapun, termasuk untuk jalan tol.

\section{Tidak Sepakat Dengan Harga Yang Ditawarkan}

Berdasarkan Perpres Nomor 65 Tahun 2006 tentang Pengadaan Tanah Bagi Pelaksanaan Untuk Kepentingan Umum, dijelaskan bahwa penentuan harga ganti rugi dilihat dari Nilai Jual Objek Pajak (NJOP) dan harga riil atau harga pasar dengan memperhatikan Nilai Jual Objek Pajak berjalan. Dalam pelaksanaan pengadaan tanah untuk pembangunan jalan Tol Trans Jawa di Kabupaten Karanganyar tersebut sebagian besar masyarakat masih tidak setuju dengan harga yang ditetapkan oleh panitia pengadaan tanah. Harga yang ditetapkan panitia pengadaan tanah harga terendahnya Rp. 228.800 dan harga tertingginya Rp. 420.000 sesuai prosedur hukum yang berlaku, tetapi menurut warga harga ganti rugi tersebut belum dapat membuat mereka menjadi lebih baik kehidupannya dengan harga ganti rugi tersebut. Seharusnya panitia pengadaan tanah juga harus memperhatikan harga 
pasaran tanah di daerah tersebut bukan hanya berpatokan pada Nilai Jual Objek Pajak (NJOP) saja.

\section{Kesimpulan}

Berdasarkan hasil penelitian dan pembahasan tersebut diatas, maka simpulan peneliti ini sebagai berikut:

1. Prosedur Pelaksanaan Pengadaan Tanah dan Penetapan Pemberian Ganti Rugi Bagi Pembangunan Jalan Tol Trans Jawa di Kabupaten Karanganyar. Dalam prosedur pelaksanaan pengadaan tanah untuk pembangunan Jalan Tol Trans Jawa di Kabupaten Karanganyar sudah sesuai dengan Peraturan Kepala Badan Pertanahan Nasional Republik Indonesia No.3 Tahun 2007 dan Peraturan Presiden Republik Indonesia No. 36 Tahun 2005 Jo. Peraturan Presiden Republik Indonesia No. 65 Tahun 2006.

Hal ini dapat dilihat pada pemberian ganti rugi kepada warga pemegang hak, ganti rugi yang diberikan hanya berpedoman pada NJOP saja. Pemberian ganti rugi tidak memperhatikan harga pasaran tanah di sekitar daerah tersebut dan tidak memperhatikan variabel-variabel yang mempengaruhi harga tanah seperti yang tercantum dalam Peraturan Kepala Badan Pertanahan Nasional Republik Indonesia No.3 Tahun 2007 Pasal 28 yang meliputi: lokasi dan letak tanah, status tanah, peruntukan tanah, kesesuaian penggunaan tanah dengan rencana tata ruang wilayah atau perencanaan ruang wilayah atau kota yang telah ada, sarana dan prasarana yang tersedia, dan faktor lainnya yang mempengaruhi harga tanah. Sehingga pada saat dilakukan penetapan ganti rugi banyak warga yang tidak setuju dengan harga yang ditetapkan.

2. Faktor-Faktor Dalam Pengadaan Tanah Untuk Pembangunan Jalan Tol Trans Jawa di Kabupaten Karanganyar Dan Upaya Yang Dilakukan Panitia Pengadaan Tanah Untuk Mengatasinya. Dari hasil penelitian yang penulis lakukan mengenai pelaksanaan pengadaan tanah untuk pembangunan Jalan Tol Trans Jawa di Kabupaten Karanganyar ini, mengalami beberapa kendala, diantaranya:

a) Adanya beberapa warga yang melakukan jualbeli lahan (tanah dijual) yang dilakukan oleh pemilik tanah secara bebas,tanpa melapor ke pihakpihak yang berwenang terhadap persoalan pertanahan. Jual beli tersebut dilakukan setelah tanah tersebut ditetapkan sebagai lokasi untuk proyek pembangunan jalan tol.

b) Terjadinya proses waris, namun masih belum ditindak lanjuti dengan proses balik nama, sehingga antara dokumen legal dengan realita kepemilikan tanah berbeda. Hal ini tentu perlu penelusuran ulang untuk memastikan siapa pihak yang berhak terhadap tanah tersebut.

c) Adanya kepemilikan inabsentia, dimana pemilik tanah tidak berada/atau berdomisili di wilayah dimana tanah tersebut berada. 
d) Pemilik hak atas tanah tidak sepakat dengan harga yang ditentukan oleh panitia pengadaan tanah karena menurut mereka harga yang ditentukan oleh panitia masih jauh dari harga pasar.

3. Upaya Untuk Menyesuaikan Asas Kesepakatan Dengan Ketentuan Musyawarah Terhadap Ganti Rugi Apabila Tidak Teracapai Kata Sepakat Tentang Besaran Nilai Ganti Kerugian Dalam Pengadaan Tanah Bagi Pembangunan Untuk Kepentingan Umum. Upaya yang dilakukan untuk mengatasi kendalakendala yang timbul dalam pelaksanaan pengadaan tanah untuk pembangunan jalan tol Trans Jawa di Kabupaten Karanganyar:

a) Adanya peran aktif dari panitia pengadaan tanah dan instansi yang memerlukan tanah melakukan musyawarah mufakat dengan pemilik hak atas tanah mengenai harga ganti rugi. Sehingga dengan dilakukan musyawarah mufakat tersebut diharapkan dapat menyelesaikan kendalakendala yang ada, terutama mengenai ganti rugi.

b) Panitia pengadaan tanah mengupayakan dengan melakukan mediasi atau pendekatan secara persuasif kepada pemilik atau pemegang hak atas tanah, yang bersikeras tidak mau melepaskan atau menyerahkan hak atas tanahnya. Dengan mengikut sertakan tokohtokoh masyarakat untuk mencapai kesepakatan mengenai harga ganti rugi. c) Panitia pengadaan tanah memberikan pemahaman dan pengertian kepada pemilik hak atas tanah, dengan melakukan penyuluhan-penyuluhan dan sosialisasi yang intensif tentang pembangunan Jalan Tol Trans Jawa di Kabupaten Karanganyar. Sehingga pemilik hak atas tanah mengerti dan memahami bahwa tanah mempunyai fungsi sosial yang bagi setiap pembangunan untuk kepentingan umum. Pemilik hak atas tanah diharapkan bersedia merelakan tanahnya untuk dipergunakan dalam pembangunan untuk kepentingan umum.

d) Panitia menitipkan uang ganti rugi atau konsinyasi lewat Pengadilan Negeri Karanganyar. Dengan dititipkannya uang ganti rugi ke Pengadilan Negeri Karanganyar, jika masyarakat keberatan dengan harga ganti rugi diperkenankan mengajukan keberatan kepada Bupati atau Walikota sesuai dengan Peraturan Kepala Badan Pertanahan Nasional Republik Indonesia Nomor 3 Tahun 2007 Pasal 40 ayat (1). Jadi dapat disimpulkan bahwa peran panitia pengadaan tanah sangat diperlukan, terutama untuk mengatasi kendalakendala yang terjadi dalam pengadaan tanah. Panitia pengadaan tanah yang merupakan kepanjangan tangan dari pemerintah daerah, memiliki peran vital 
bukan saja dalam melakukan pengadaan tanah melainkan menyelesaikan masalahmasalah yang timbul antara pihak yang membutuhkan tanah dengan pihak yang memiliki tanah.

\section{Saran}

Berdasarkan kesimpulan penelitian maka penulis dapat mengemukakan saran-saran sebagai berikut:

1. Disarankan agar Pemerintah Pusat dan Daerah ,khususnya Kantor Pertanahan Kabupaten Karanganyar berkewajiban memberikan pemahaman yang mendalam mengenai Peraturan Presiden No. 36 Tahun 2005 Jo Peraturan Presiden Nomor 65 Tahun 2006 tentang pengadaan tanah melalui pembinaan penyuluhan hukum, khususnya hukum pertanahan (Agraria) baik kepada aparat pemerintah kecamatan, desa/kelurahan, maupun tokoh dan masyarakat secara intensif sehingga pelaksanaannya lebih baik dimasa yang akan datang.

2. Disarankan agar panitia pengadaan tanah, dalam menetapkan nilai ganti rugi hendaknya tidak hanya berpatokan pada Nilai Jual Objek Pajak (NJOP) saja, karena sebagaimana diketahui bahwa NJOP tidak selalu sama dengan harga pasaran sebenarnya. Dan hendaknya dalam menentukan ganti kerugian tersebut harus mempertimbangkan unsurunsur kemanusiaan.
3. Hendaknya masyarakat yang tanahnya terkena pembangunan Jalan Tol Trans Jawa di Kabupaten Karanganyar lebih memahami mengenai fungsi sosial atas tanah, sehingga tidak meminta ganti rugi yang begitu tinggi agar pengadaan tanah untuk pembangunan Jalan Tol Trans Jawa dapat diselesaikan.

\section{DAFTAR PUSTAKA}

Aslan Noor, 2006, “Konsepsi Hak Milik Atas Tanah Bagi Bangsa Indonesia'. Bandung: $\mathrm{CV}$. Mandar Maju.

Boedi Harsono, 2003, “Hukum Agraria Indonesia ( Sejarah Pembentukan Undang-Undang Pokok Agraria, Isi dan Pelaksanaannya", Djambatan, Jakarta.

Mudakir Iskandar Syah, 2007, "Dasar-Dasar Pembebasan Tanah Untuk Kepentingan Umum”, Jala Permata, Jakarta.

Muhammad Yamin Lubis dan Abdul Rahman Lubis, 2011, "Pencabutan Hak, Pembebasan dan Pengadaan Tanah", Mandar Maju, Bandung.

\section{Peraturan Perundang-Undangan}

Undang-Undang Dasar Negara Republik Indonesia Tahun 1945 
Undang-Undang Nomor 5 Tahun 1960 Tentang Peraturan Dasar Pokok-Pokok Agraria

Undang-Undang Nomor 2 Tahun 2012 Tentang Pengadaan Tanah Bagi Pembangunan Untuk kepentingan Umum

Peraturan Presiden Nomor 36 Tahun 2005 tentang Pengadaan Tanah Bagi Pelaksanaan Pembangunan Untuk Kepentingan Umum

Peraturan Presiden Nomor 65 Tahun 2006 tentang Perubahan Atas
Peraturan Presiden Nomor 36 Tahun 2005 Tentang Pengadaan Tanah Bagi Pelaksanaan Pembangunan Untuk Kepentingan Umum 